\title{
AAAS annual meeting draws largest crowd of decade
}

\section{San Francisco}

THE annual meeting of the American Association for the Advancement of Science (AAAS) in San Francisco drew nearly 10,000 scientists, journalists and members of the public, making it the largest, and according to its organizers, the most successful meeting of the decade.

But the annual meeting still lacks a clear identity, and efforts to move it closer to a mainstream scientific meeting were not an unqualified success.

Since a low of only 2,300 people attending the Los Angeles meeting in 1985, AAAS has worked hard to boost attendance at its meetings. One approach that outgoing AAAS president Walter Massey credits with attracting a broader audience to the meetings has been special scientific symposia. These symposia, requiring a separate registration fee, were first held three years ago. This year's symposia on plant molecular genetics and protein folding drew standing-room-only crowds in 500 -seat ballrooms.

But in neighbouring rooms of equal size, scientific symposia covering similar basic science topics seemed empty by comparison. Twelve sessions over four days brought top scientists from around the country to San Francisco for sessions on cellular receptors, developmental biology and gene expression and retroviruses and oncogenes, but audiences were disappointingly small.

Corey Goodman, professor of biochemistry at the University of California at Berkeley, who co-organized the developmental biology session, says he was mortified to find only 60 or 70 people in a hall that holds 500 listening to a paper presented by Harvard's Philip Leder.

Goodman maintains that a similar talk would have drawn hundreds at any of the San Francisco area's research universities. Each of the scientific sessions had several scientific luminaries who would typically draw large crowds, but none was well attended.

Goodman also complains that after exhorting him to coax the best scientists to come to the meeting, often at their own expense, AAAS then did little or nothing to promote attendance at the sessions. Goodman says that others who were asked to organize special symposia were similarly disappointed by the results.

Massey says he is not sure why these sessions failed to attract larger audiences, and the problem will have to be sorted out before the next meeting.

The San Francisco meeting did have its own social issues. A polite demonstration by an AIDS activist group disrupted an awards ceremony for AIDS researcher
Anthony Fauci, director of the National Institute of Allergy and Infectious Diseases.

Outside the meeting, animal rights activists distributed leaflets and held posters protesting at the use of animals for scientific research. The AIDS protesters threw confetti as part of their protest against the red tape involved in approving new AIDS drugs, said Massey, a stark con rast to the 1971 meeting in Philadelphia at which protesters threw blood in an anti-war protest.

The most controversial session of the current meeting occurred on the last day, when J. Philippe Rushton of the University of Western Ontario presented a paper using anatomical, genetic and behavioural studies as a basis for claiming that blacks exhibit less sexual restraint, have lower intelligence and have more violent temperaments than Caucasians or Asians. When news of the Rushton talk began circulating among the 771 journalists registered for the meeting, Massey was brought to a hurriedly scheduled press conference to deny that AAAS supported Rushton's theories, but to emphasize that it supported his right to express his opinion.

As an organization, AAAS is in the midst of change. In addition to the annual meeting, AAAS's most visible role is as publisher of Science. But the organization also has active programmes in public understanding of science, arms control and human rights. From 1975 until 1987, William Carey served as AAAS executive director, and with an insider's background in the workings of Washington, Carey put AAAS in the thick of the US science policy debates.

Carey was replaced by Alvin Trivelpiece, who had previously been an assistant secretary at the Department of Energy where he was widely credited with convincing President Reagan that he should approve plans to build the Super-conducting Super Collider.

But Trivelpiece resigned late last year to become director of the Department of Energy's Oak Ridge National Laboratory. His leadership was too short to establish any clear direction for the organization. Former Science editor Philip Abelson is acting executive director while the search for a successor proceeds.

AAAS has embarked on a series of long-term reviews on where it has been and where it is going. Massey is confident that the annual meetings will regain much of the vitality they had in the 1960 s and early 1970s, when AAAS became a focus for the intersection of science and society.

Joseph Palca

\section{Nuclear plant presents unique problems}

\section{Boston}

ThE first attempt ever to decommission a commercial nuclear power plant reached a crucial milestone last month when the reactor vessel of the Shippingport Atomic Power Station was hoisted out of its underground site. The reactor's removal is perhaps the largest single step in the Energy Department's five-year, \$98-million project to decommission the power plant, located outside Pittsburgh, Pennsylvania, but many steps still remain.

Built in 1957 as part of the "Atoms for Peace" programme, Shippingport was the world's first nuclear plant to operate solely for the production of electricity. It closed in 1982, and work on dismantling it has been going on for three years.

The 72-MW reactor was constructed in a joint venture between the now-defunct Atomic Energy Commission (AEC) and a private utility, and the government agreed at the time of its construction to take charge of its decommissioning.

All other US commercial reactors will have to be decommissioned by the utility companies that built them, focusing industry interest on the Shippingport project. In the United States, 15 plants are expected to be ready for decommissioning by the year 2000 .

The Department of Energy (DoE) wants to use the Shippingport reactor as a model programme for decommissioning. But some critics say that experience gained at Shippingport will have limited relevance to future decommissioning, and will only emphasize the obstacles others will face.

The most glaring obstacle is that in the United States there is still no high-level nuclear waste repository for spent fuel rods from commercial reactors, and virtually no place to deposit low-level waste. All three of the existing low-level facilities are close to capacity and nearing the end of their designed life-spans. For commercial reactors now and in the foreseeable future, disposal of radioactive refuse from a decommissioned plant would be impossible.

But even beyond the disposal problem, critics say that DoE is not making as much of the exercise as it could for testing and evaluating techniques needed in the future. They also object to DoE's decision to remove the reactor vessel for disposal in its entirety rather than cutting it into pieces on site as will be necessary for larger plants. Even with the reactor vessel's removal, the job is far from over. On the Shippingport site, two more years of work are expected.
Seth Shulman 